Printed in Great Britain

\title{
AN EXAMINATION OF THE ORIGINAL SLIDES OF MARINE ACARI OF HODGE, I863
}

\author{
By H. C. Fountain \\ (Text-figs. I-3)
}

During work on Halacaridae collected in the Plymouth area it became apparent, in view of variations in diagnostic characters among certain species, that it would be useful and interesting to trace and examine as many as possible of the original specimens described and figured by the early British workers in this group of water mites.

Johnston (1836) described Acarus basteri, and Gosse (1855) described and figured three species of marine mites, Halacarus rhodostigma, H. ctenopus and Pachygnathus notops. In the same year Hodge (1855) figured a species of the genus Pachygnathus (namely $P$. seahami), and remarked that with those of Gosse 'to the best of my knowledge, these are the only recorded British species'. Hodge (I863) described and figured four new species: Halacarus granulatus, H. oculatus, Pachygnathus minutus and Leptognathus falcatus. By the courtesy of $\mathrm{Mr} \mathrm{G}$. E. Fisher, Curator of the Hancock Museum, Newcastle-upon-Tyne, I have been able to examine Hodge's original slides; these will be described later in this paper. Brady (1875) described four new species, namely Trombidium fucicolum, Pachygnathus sculptus, Gamasus marinus and Cheyletus robertsoni. The remaining mites dealt with in his review were Pachygnathus notops, P. seahami, Leptognathus falcatus, Halarachne halichoeri Allman, Halacarus rhodostigma, H. granulatus, H. oculatus, H.ctenopus and Pachygnathus minutus. Of these mites Trombidium fucicolum and Scutovertex minutus (=sculptus Mich.) are oribatids, Gamasus marinus is the mite Halolaelaps marinus (syn. glabriusculus) and Cheyletus robertsoni is $C$. eruditus. Of the others he placed Leptognathus falcatus in the genus Raphignathus Dugés, and Hodge's species oculatus and granulatus were made synonyms of Gosse's Halacarus rhodostigma.

In dealing with Hodge's Pachygnathus minutus Brady remarks 'I strongly suspect that it may prove to be an early stage of the following species'. This 'following species' he proceeds to describe as P. sculptus n.sp. As will be seen Brady was right in his suspicion and Hodge's $P$. minutus is the larval form of the mite now known as Simognathus sculptus (Brady). Sculptus therefore becomes a synonym of minutus. Brady's conclusion that Halacarus granulatus Hodge and H. oculatus are the same mite as Gosse's H. rhodostigma is not correct in the case of the first, but is true of oculatus (see Fig. I B, C).

The complete collection of Hodge's slides (eight in number) lent to me by $\mathrm{Mr}$ Fisher will now be considered and some of them described and 
figured. The transparency of the slides varies from perfectly clear and colourless to absolutely opaque. This last state was that of the Type slide of Leptognathus falcatus, but after treating it I was able to make a figure of the mite in some detail.

(I) Pachygnathus minutus-taken at Seaham. The mountant of the slide is discoloured but transparent. The mite is mounted to show the ventral aspect (Fig. I A). The slide bears a label, in addition to Hodge's label, 'See Brady,

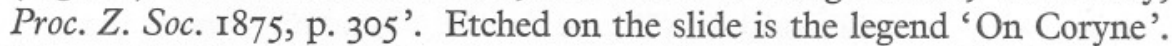
The surface (ventral) of the mite presents the appearance of shrinkage into the semblance of a fairly coarse network. The specimen is a larva having only six legs. There are several specimens of the diatom Grammatophora marina (Lyngb.) attached to the outside surface of the mite. The dotted lines in the figure indicate the shapes of the pre- and post-dorsal plates which can be seen by 'focusing down'. By the courtesy of Mr E. Browning of the British Museum (Natural History) I was able to compare this slide with one of Simognathus sculptus from the Canon Norman collection of Halacaridae in the British Museum, which comparison leaves no doubt as to the identity of Pachygnathus minutus with the Simognathus sculptus of Brady. The specimens on both Hodge's and Norman's slides were from the Durham coast littoral zone. Of S. sculptus Brady, André (1946, p. 138) writes: 'Cette espèce a été rencontrée sur les fonds rocheux de la zone littorale, entre Io et 65 mètres de profondeur, dans la mer du Nord (Angleterre) et dans l'Atlantique (Le Croisic).'

Of the mite, Hodge himself says, 'Legs smooth, with the exception of the 5 th and 6th joints, which have a few short stout hairs. Legs and rostrum irregularly dotted with minute granules; other markings in character. The posterior portion of the body minutely corrugated.... This curious species occurred on some stems of Coryne eximia from between tide marks, and from the specimen obtained possessing only three pairs of legs it would appear to be a young individual.'

Lohmann (1889, p. 333), in describing 'Aletes' minutus (Hodge) says, 'Was Brady bewog, in dieser Larve ein Jugenstadium seines Pachygnathus sculptus $\mathrm{zu}$ vermuthen, weiss ich nicht. Anhaltspunkte dafür existieren jedenfalls nicht.' Lohmann evidently had not seen Hodge's slide.

(2) Halacarus oculatus (Fig. I B) - taken at Seaham. The mountant ${ }^{1}$ of this slide has become slightly brown. Like the previous slide it bears an added label, 'See Brady, Proc. Z. Soc. I875, p. 310.'

1 Lifting the label mentioned above on the 'oculatus' slide reveals an inscription probably made by Hodge, scratched by a diamond on the glass, 'Deep Water 26.4.6I Deans Medium'. As already mentioned, the state of discoloration of the mountant varies from clear to opaque. Mr Fisher seemed to consider the mountant to be Canada Balsam, but from this inscription it may be that all are mounted in Dean's medium. 

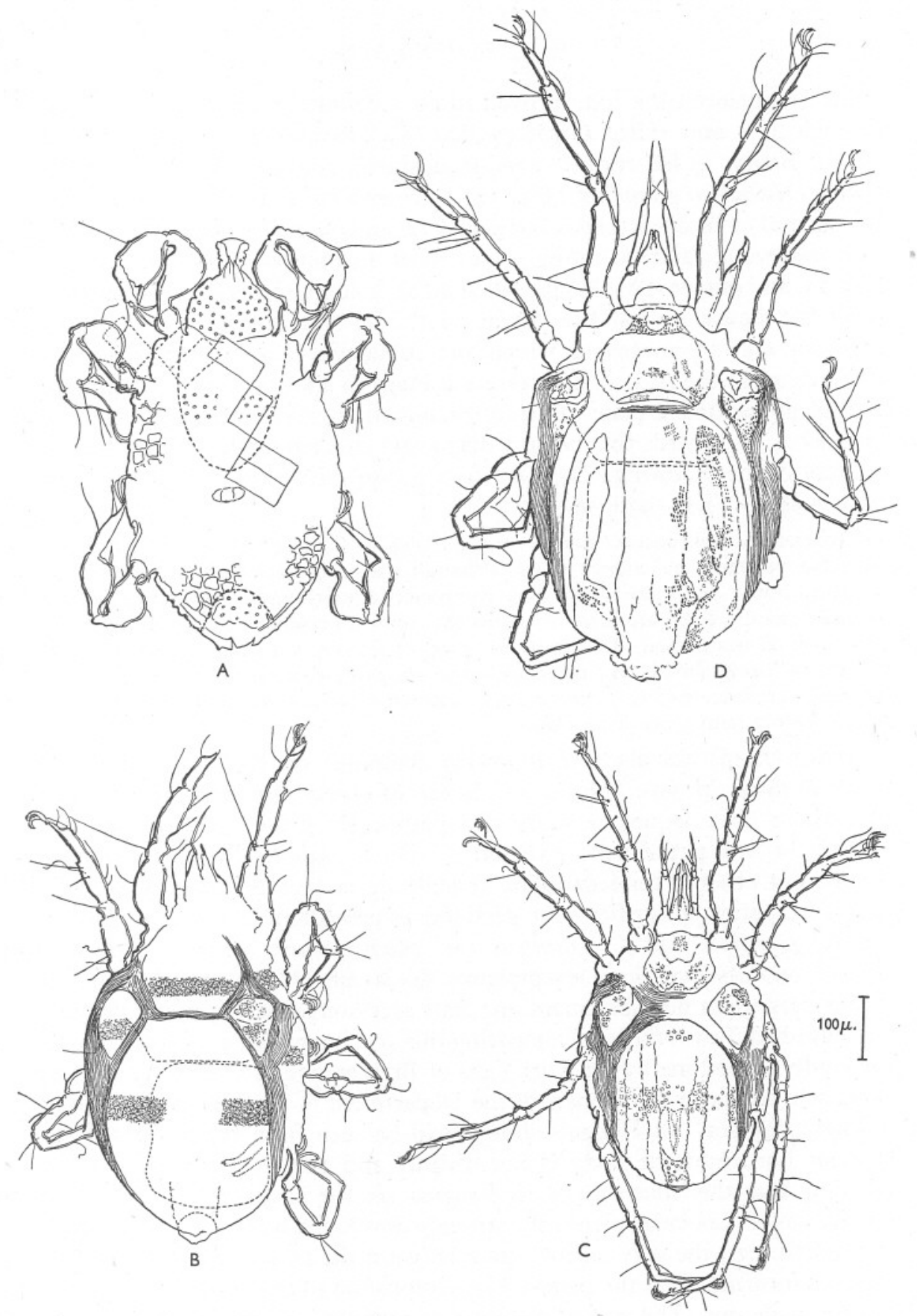

Fig. I A. Pachygnathus minutus. The larval form of the mite now to be known as Simognathus minutus (Hodge, 1863). B, Halacarus oculatus. This is the mite known as Copidognathus rhodostigma (Gosse, I855) and must be regarded as an error in identification by Hodge. c, Halacarus granulatus. This is the mite known as Copidognathus glyptoderma; it must now be called C. granulatus (Hodge, I863). D, Halacarus rhodostigma. This is another error in identification and is the mite now known as Copidognathus gracilipes (Troues., I894). 
On examination the mite proved to be a definitely different animal from that which is now called Copidognathus (Copidognathopsis) oculatus (Hodge, I863). Brady, in his review mentioned above, considers this, and the following (Halacarus granulatus, Fig. I c), to be synonymous with H. rhodostigma Gosse; and of Hodge's oculatus he says: ' $H$. oculatus is, I think, without doubt only the young; and excepting some trivial distinction of surface markings, I cannot find out what $\mathrm{Mr}$ Hodge relied on to distinguish his supposed species.'

As the figure shows, the ocular plates do not possess the drawn-out posterior end by means of which the subgenus is at present diagnosed. Unfortunately the slide is not perfect enough to allow a view of the anterior margin of the dorsal plate. Careful examination reveals faint pectination of the claws. As regards this being a diagnostic character it will be well to take account of the following. Newell (1947, p. I50), in writing of Copidognathus curassaviensis Viets 1936, says:

The presence or absence of combs on the claws of Copidognathus species is an undesirable primary key character, for although there are many species with clearly pectinate claws, and some which have completely smooth claws (but usually with an accessory tooth), there are many in which the comb is present but difficult to observe, even with oil immersion. In this latter group of species which are apparently in the process of losing the pecten, there are unquestionably some species which show individual variation (e.g. C. acutus n.sp.), some specimens having smooth claws, and others having faintly pectinate claws.

André (1946) has also the following footnotes on the same point. On C. rhodostigma (p. 90): 'Motas et Soarec ont observé un individu mâle de la mer Noire chez lequel, à toutes les pattes, les griffes sont pectinées et présentent une petite dent accessoire.' On C. tabellio (p. 94): 'Motas et Soarec ont observé un échantillon femelle de la mer Noire chez lequel, à toutes les pattes, les griffes sont pectinées et présentent une dent accessoire.' On C. gracilipes and C. gracilipes var. quadricostatus (p. I04): 'Motas et Soarec ont observé deux exemplaires de la mer Noire chez lesquels les griffes présentent non seulement une dent accessoire, mais aussi un peigne.'

I have had the privilege of comparing this specimen with a slide of $C$. oculatus kindly loaned me by Dr Karl Viets of Bremen and also with slides of the same sent to me by Dr Hobart of the Department of Agriculture and Forest Zoology, Bangor. In Hodge's slide it will be seen from the figure that the anterior border of the body is not distinct and the chief features used in deciding that this specimen is rhodostigma are the absence of the posterior elongation of the ocular plates, the strongly developed hair of the 3 rd segment of the first legs, the very narrow space between the two dorsal plates and the even sculpturing of all the plates. The sculpturing of the ventral plates could not be made out. The size of the mite as mounted is length approx. $360 \mu$, breadth $230 \mu$. In a letter on the subject of these 'old' slides Dr Viets says: '.. only the Hodge slides may be type specimens of his species, I think'. It seems that we must regard this specimen as wrongly identified by Hodge, 
and Lohmann's (I889) description, which is clearly that of the oculatus of to-day, must be taken as the description of the type.

(3) Halacarus granulatus (Fig. IC) taken at Seaham. This slide, as the two previous, bears a label, 'See Brady, Proc. Z. Soc. I875, p. 310'. This specimen is undoubtedly the species now known as Copidognathus glyptoderma Trouessart. Trouessart's species must therefore sink and the type of the genus Copidognathus must be renamed $C$. granulatus (Hodge). The size of the mite is $480 \times 35^{8} \mu$. The sculpturing of the posterior dorsal plate, with its four longitudinal bands, is as shown in the figure of C. glyptoderma in André, while that of the anterior dorsal plate is a good approximation allowing for some slight deterioration of the mountant. The suggestion of three sculptured areas which André calls 'trois impressions saillantes disposées en triangle', and the subquadrangular shape of the anterior dorsal plate are also in agreement. Of the ocular plates André's description is 'subquadrangulaires, assez grandes, arrondies à leur angle antérieur et se prolongeant en arrière par une pointe bien marquée. Elles portent chacune une grande cornée antérieure et deux beaucoup plus petites, rudimentaires, en arrière de la précédente.' These two rudimentary cornea are not visible on Hodge's specimen, and although André mentions them they do not seem to be shown in his figure. The posterior dorsal plate is separated from the anterior dorsal plate by a band of dermal tissue about $2 \frac{1}{2}$ times as broad as long (André says, 'deux fois plus large que haute'). The general oval shape, the very strong pectination of the claws and the minute denticles on the mandibles also agree with André's description, leaving no doubt that this specimen is the C. glyptoderma of Trouessart.

(4) Halacarus rhodostigma, 20 fathoms, I6 May I86I (Fig. ID). This specimen is, according to present-day diagnosis, wrongly identified, and is a specimen of the species known as Copidognathus (Copidognathopsis) gracilipes (Trouessart, I889). Dr I. M. Newell (I947) has placed this species in a new subgenus, and on p. 34 writes:

...there is a group of species which formerly were placed in the subgenus Copidognathopsis, but which are distinct from all other species of Copidognathus in the number of ventral setae on tibia I. The other species of Copidognathus are remarkable for the apparently absolute constancy of the number (three) and arrangement (two ventromedial; one ventral or ventro-lateral) of the ventral setae on the first and second tibiae. But in C. arenarius n.sp., C. submarinus n.sp., C. gracilipes gracilipes (Trouessart, I889), C. gracilipes quadricostatus (Trouessart, I894) and C. gracilipes largiforatus (Trouessart, I889) there are two pairs of ventral setae on $I-5$ in both the deutonymph and the adult. These five forms are more closely related to each other than to any species in the genus and therefore form a distinct and natural species group. All have a short, blunt, rostrum which extends only a little beyond the middle of $\mathrm{P}-2$, and apparently all lack rosette pores on any of the plates. The above five forms are removed to 
Arhodeoporus n.subg. The name indicates the absence of rosette pores, but this is not the most important character on which the subgenus is based. Furthermore, not all 'arhodeoporose' species belong here.

Concerning this new subgenus of Newell's, Viets (I950) makes the following remarks:

Newell 1947 trennt nun subgenerisch von Copidognathus (Copidognathus), nach ihm die Arten mit 3 (unpaaren) Ventralborsten an den I.B.5 umfassend, als Copidognathus (Arhodeoporus) die Arten ab, die 4, also paarige Ventralborsten an den I.B.5 tragen. Diese Unterschiede und andere unterschiedliche Merkmale (in der Plattenstruktur, p. 35 'apparently (sic!) all lack rosette pores' und in der basalen Breite und Länge des Rostrum relativ zur Palpenlänge) sind subgenerisch mindestens ebenso unbefriedigend, wie die immerhin messbaren Merkmale und Unterschiede in den Okularia. Da die ganz charakterischen Okularia der neben Copidognathus (Copidognathopsis) gracilipes (Trt. 1889) von Newell in Arhodeoporus gestellten Arten arenarius New. und submarinus New. typische Merkmale von Copidognathopsis zum Ausdruck bringen, vermag ich in Arhodeoporus New. nur ein Synonym zu Copidognathopsis zu sehen.

In the Hodge specimen the two pairs of ventral setae can be seen on the right $\mathrm{I}-5$, the short blunt rostrum is evident and a careful examination, using a $4 \mathrm{~mm}$. apochromatic objective, fails to reveal any rosette pores. In all respects the mite also agrees well with André's description of $C$. gracilipes; the ocular plates and the dorsal plates with their distinctive sculpturing being especially convincing. The size of the specimen is $450 \times 280 \mu$.

(5) Halacarus rhodostigma (Fig. 2). The mountant of this slide is dark brown in colour, but as the figure shows the mite is fairly visible and but for the faint pectination of the claws it agrees as far as it is possible to judge with the present Copidognathus rhodostigma. The view is ventral and the shapes of the dorsal plates are indicated by dotted lines. The specimen is a male, size 4 I $2 \times 2$ II $\mu$ and the sculpturing and general appearance agrees with André's description.

(6) This slide (not figured) is Hodge's slide of Pachygnathus seahami and is labelled 'Type'. Added inscription on the label is 'Rocks I86I'. There are six specimens on the slide and, although the mountant is perfectly clear and unstained, the specimens themselves are opaque for the most part. The terminal segments of most of the legs in each specimen are visible and are really the only characters it is possible to use for identification. Using these and the faint indication of the provisional genital area in some specimens I make them out to be:

Length $(\mu)$
(I) Adult
(2) Adult
425
(3) Adult
430
(4) Deutonymph
(5) Deutonymph
475
340
370
335
All four medial claws large
All four medial claws large
All four medial claws large
Medial claws 3 and 4 small
Medial claws 3 and 4 small
Medial claws 3 and 4 small

All are the mite now known as Rhombognathus (Rhombognathopsis) seahami. 
(7) This slide is also labelled Pachygnathus seahami and is of a very damaged specimen. There is only one specimen on the slide and the condition of the mountant is perfect as in the last slide. On the end of the glass slip is etched 'Deep Water 1860'. Using the same features as in the last slide I have no doubt of its being a true seahami.

(8) Leptognathus falcatus Hodge I860. This mite (Fig. 3) is labelled 'Type'. When sending me this slide Mr Fisher said in his accompanying letter,

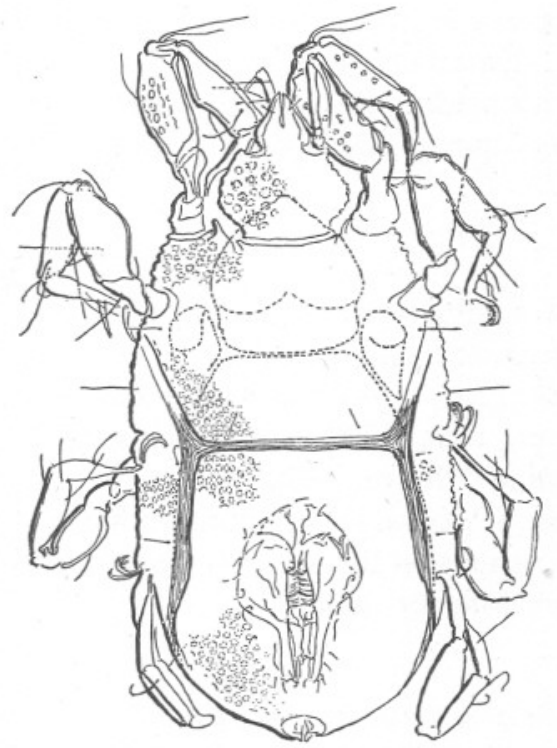

Fig. 2

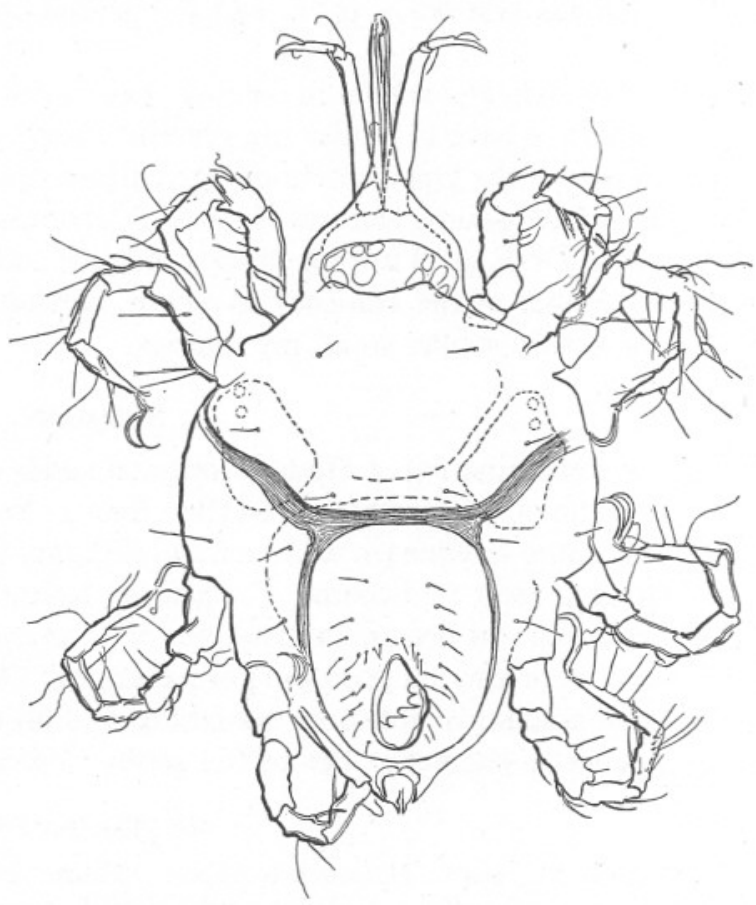

Fig. 3

Fig. 2. Halacarus rhodostigma. This mite was correctly identified by Hodge and the figure is given for comparison with Fig. ID.

Fig. 3. Leptognathus falcatus. Hodge's type slide. This mite is now Lohmanella falcata (Hodge, r863).

'. .. and Leptognathus falcatus, Seaham. Unfortunately the balsam of the latter slide has disintegrated so that the specimen will be of very little use.' A prolonged soaking in xylene had no effect on the mountant and a similar treatment with chloroform met with no more success. This seems to indicate that the mountant was not Canada Balsam but almost certainly Dean's Medium. The slide was then immersed in cellosolve and 'forgotten' for about I8 months. It was then possible to see the amount of detail shown in Fig. 3. Because of the danger of destroying the specimen by moving the cover-glass the drawing was made in instalments; the slide being returned to the cellosolve when 
drying-up of the liquid was reaching the danger point. This is the condition of things at the time of writing. The legend 'Deep Water March I86I' is scratched on the slide by means of a diamond point. The details shown in the figure were obtained by the use of 'phase-contrast' methods and I think the figure is sufficiently detailed to confirm the identity of the specimen with the animal now known as Lohmannella falcata (Hodge). The aspect shown is as mounted (ventral) and as much of the dorsal plates and the ocular plates as could be made out is indicated by dotted lines in the figure. The specimen is a female, size $605 \times 345 \mu$, and the genital opening is $66 \times 40 \mu$.

For help and advice in writing these notes, as well as for material for comparison, I have to tender my grateful thanks to Dr K. Viets of Bremen, Dr J. Hobart of the Department of Agriculture, Bangor, and Mr E. Browning of the British Museum (Natural History, Arachnida). Especially have I to thank my friend Dr F. A. Turk for much guidance and for reading this paper, and also Mr Fisher of the Hancock Museum, Newcastle-upon-Tyne, for his patience and kindly replies to all my queries.

\section{SUMMARY}

An examination of Hodge's original slides of marine Acari shows that three alterations in synonymy are called for: (i) Simognathus sculptus (Brady, I875) to become a synonym of S. minutus (Hodge, I863); (ii) Copidognathus oculatus Hodge, I860 to become C. oculatus Lohmann, I889; (iii) C. glyptoderma Trouessart to become a synonym of C. granulatus (Hodge, I863). Observations were also made on the permanence of Dean's Medium as a mountant for small arachnids and some quotations and observations on the value of certain diagnostic characteristics of the genus Copidognathus are made.

\section{REFERENCES}

ANDRÉ, M., I946. Halacariens Marins. Faune de France, T. 46, I52 pp., Paris.

BRADY, G. S., I875. A review of the British marine mites, with descriptions of some new species. Proc. Zool. Soc. Lond., I875, pp. 30I-II.

Gosse, P. H., I855. Notes on some new or little-known marine animals. Ann. Mag. Nat. Hist., Ser. 2, Vol. 16, pp. 27-36; 305-13.

HodGE, G., I855. Contributions to the zoology of Seaham harbour. I. On a new marine mite (Pachygnathus seahami). Trans. Tyneside Nat. Field Club, Vol. 4, p. 31 .

- I863. Contributions to the marine zoology of Seaham harbour. On some undescribed marine Acari. Trans. Tyneside Nat. Field Club, Vol. 5, pp. 298-303.

Johnston, G., I836. Illustrations in British zoology. Acarus basteri. Mag. Nat. Hist., Vol. 9, pp. 353-5.

Lohmann, H., I889. Die Unterfamilie der Halacaridae Murr. und die Meeresmilben der Ostsee. Zool. Fahr., Bd. 4, pp. 269-404.

Newell, I. M., I947. A systematic and ecological study of the Halacaridae of eastern North America. Bull. Bingham Oceanogr. Coll., Vol. Io, Art. 3, 232 pp.

VIETS, K., I950. Die Meeresmilben (Halacaridae, Acari) der Fauna Antarctica. Further Zoological Results of the Swedish Antarctic Expedition 1901-1903, Vol. 4, No. 3, 44 pp. Stockholm. 